KINETIK, Vol. 2, No. 1, Februari 2017, Hal. 1-8

ISSN : 2503-2259,

E-ISSN : 2503-2267

\title{
Penentuan Kombinasi Jumlah Katalis Dalam Produksi Metanol Menggunakan Metode Fuzzy dan Evolution Strategies
}

\author{
Angga Santoso \\ Universitas Brawijaya \\ angga.email.kuliah@gmail.com
}

\begin{abstract}
Abstrak
Sebagai salah satu bahan baku utama dalam berbagai industri kimia, cara yang paling umum digunakan dalam memproduksi metanol adalah melalui proses hidrogenasi karbon. Proses ini hanya dapat dilakukan dalam suhu yang sangat tinggi dan untuk mencapai suhu tersebut membutuhkan waktu yang sangat lama. Salah satu cara untuk mengurangi kebutuhan suhu tersebut adalah menggunakan suatu campuran senyawa kimia yang disebut katalis. Komposisi jumlah katalis yang tepat dan suhu yang sesuai merupakan faktor penting yang menentukan banyaknya produksi metanol yang dihasilkan. Mencari angka yang tepat dari semua kemungkinan melalui uji coba di laboratorium membutuhkan banyak waktu. Oleh karena itu, metode Fuzzy digunakan untuk menghitung banyaknya hasil produksi berdasarkan beberapa percobaan di laboratorium dan algoritma evolution strategies digunakan untuk mencari kombinasi jumlah katalis yang tepat. Katalis yang digunakan dalam uji coba adalah $\mathrm{CuO}-\mathrm{ZnO}-\mathrm{ZrO}_{2}$. Metode Fuzzy yang digunakan memperoleh akurasi sebesar $80.7 \%$ dengan membandingkan hasil dari laboratorium. Dari algoritma evolution strategies diperoleh produksi methanol paling besar pada komposisi jumlah katalis $40 \% \mathrm{Cu}, 40 \% \mathrm{Zn}, 20 \% \mathrm{Zr}$, dan suhu $230^{\circ} \mathrm{C}$. Komposisi tersebut dapat digunakan untuk memproduksi methanol dengan hasil paling banyak tanpa harus mencoba semua kemungkinan komposisi.
\end{abstract}

Kata Kunci: Katalis, Metanol, Hidrogenasi karbon, Evolution strategies, Fuzzy inference system

\begin{abstract}
Methanol, as one of primary ingredient in various chemical industries, is commonly produced through hydrogenation of carbon. This process needs to be conducted in a very temperature, in which takes a lot of time to reach. However, there is one way to decrease the temperature needs that is by using a chemical compounds called catalysts. The correct composition of catalyst and appropriate temperature determine the amount of methanol being produced. Yet, finding the correct number from all possibilities obtained through experiments in laboratory is time consuming. Therefore, Fuzzy method is employed to calculate the production result from several experiments and algorithm evolution strategy is utilised to find the perfect catalyst combination. The catalyst being used in the experiments is $\mathrm{CuO}-\mathrm{ZnO}-\mathrm{ZrO}_{2}$. The accuracy of Fuzzy method compared to Laboratory result is $80.7 \%$. Meanwhile, algorithm evolution strategy foiund that the production of methanol reach its highest when the catalyst combination is $40 \% \mathrm{Cu}, 40 \% \mathrm{Zn}, 20 \% \mathrm{Zr}$, and the temperature is $230^{\circ} \mathrm{C}$. This composition can be used to produced the biggest number of methanol without wasting too much time testing all the possibilities.
\end{abstract}

Keywords: Catalyst, Methanol, Hydrogenation of carbon, Evolution strategies, Fuzzy inference system

\section{Pendahuluan}

Methanol merupakan bentuk senyawa paling sederhana dari alkohol dengan rumus kimia $\mathrm{CH}_{3} \mathrm{OH}$. Dalam kehidupan sehari-hari methanol dikenal sebagai Spiritus. Dalam industri kimia dan energi, methanol merupakan bahan baku primer yang sangat penting. Sehingga kebutuhan methanol di dunia pada tahun 2012 mencapai 58.6 MMT [1]. Methanol berperan sebagai bahan pelarut dan bahan baku dalam produksi senyawa kimia lain, seperti formalin dan asam asetat [2]. Secara alami, methanol juga dapat dimanfaatkan sebagai sumber energi alternatif campuran bensin [3] dan sebagai sel bahan bakar (fuel cell) [4].

Methanol dihasilkan dalam jumlah kecil dengan bentuk uap methanol di alam melalui proses metabolisme anaerobik bakteri, namun untuk memenuhi kebutuhan komersial industri 
kimia dan energi, methanol dapat diproduksi melalui sintesis gas alam, gasifikasi batu bata, dan penyulingan kayu. Sintesis gas alam atau dalam dunia kimia dikenal sebagai hidrogenasi karbon yang digunakan untuk memproduksi methanol dalam jumlah besar. Proses hidrogenasi karbon dapat membantu mengurangi kadar emisi karbon di atmosfer, karena mengonversi karbon menjadi senyawa-senyawa baru yang bermanfaat seperti methanol [5].

Proses hidrogenasi karbon hanya dapat berlangsung dalam kondisi suhu yang sangat tinggi, yaitu sekitar $800^{\circ} \mathrm{C}$. Untuk mencapai suhu yang dibutuhkan, diperlukan energi tinggi dan waktu yang lama. Oleh karena itu, ditambahkan senyawa kimia lain pada proses reaksi hidrogenasi karbon untuk menekan kebutuhan suhu yang sangat tinggi. Senyawa kimia tersebut dikenal sebagai katalis. Katalis sangat memberi dampak signifikan dalam proses reaksi dengan menurunkan suhu yang dibutuhkan menjadi sekitar $200^{\circ} \mathrm{C}-300^{\circ} \mathrm{C}$.

Dalam beberapa tahun terakhir, katalis paling banyak digunakan dalam industri adalah $\mathrm{Cu}, \mathrm{Zn}, \mathrm{Cr}$, dan Pd karena memberikan pengaruh paling besar dalam menurunkan kebutuhan suhu dan meningkatkan jumlah methanol yang dihasilkan [6]. Katalis-katalis kemudian digabungkan satu sama lain untuk memperbesar pengaruh yang diberikan. Namun, menggabungkan katalis-katalis dapat menimbulkan permasalahan mengenai komposisi yang tepat dari masing-masing katalis. Memperbanyak jumlah katalis tidak hanya membuang sumber daya, namun dapat menurunkan hasil produksi methanol.

Hasil penelitian menunjukkan berbagai kombinasi katalis dapat memberikan hasil berbeda [7]. Setiap kombinasi katalis memiliki komposisi dan kebutuhan suhu berbeda-beda, sehingga banyak dilakukan penelitian untuk mencari komposisi katalis dengan suhu yang tepat untuk masing-masing gabungan katalis dengan melakukan uji coba di laboratorium. Dalam salah satu penelitian sebelumnya [8], dilakukan uji coba laboratorium terhadap 10 macam komposisi katalis gabungan $\mathrm{CuO}-\mathrm{ZnO}-\mathrm{ZrO}_{2}$. Didapatkan komposisi katalis paling optimal berapa pada komposisi $38.2 \% \mathrm{Cu}, 28.6 \% \mathrm{Zn}, 33.2 \% \mathrm{Zr}$, dan suhu $240^{\circ} \mathrm{C}$.

Hasil dalam penelitian tersebut dapat dikatakan bukan yang paling optimal, disebabkan komposisi pengujian hanya 10 macam kombinasi dan didapatkan secara acak, sehingga hasil tersebut merupakan yang paling optimal dari 10 macam kombinasi, bukan dari keseluruhan kombinasi. Untuk mengatasi kelemahan tersebut, penulis menggunakan metode Fuzzy untuk menghitung perkiraan produksi menggunakan data uji coba dari laboratorium dan algoritma evolution strategies untuk mencari kombinasi komposisi yang paling tepat.

\section{Metode Penelitian}

\subsection{Metode Fuzzy}

Metode Fuzzy merupakan metode untuk membantu memutuskan atau memecahkan suatu permasalahan dengan menggunakan basis aturan IF-THEN. Dalam penelitian ini, logika Fuzzy yang digunakan adalah Fuzzy Tsukamoto. Rule yang digunakan dibuat berdasarkan data pada Tabel 1 diperoleh dari hasil uji coba di laboratorium [8].

Tabel 1. Hasil Uji Coba Laboratorium

\begin{tabular}{ccccccccc}
\hline \multirow{2}{*}{ Sample } & \multicolumn{3}{l}{ Komposisi Katalis (\%) } & \multicolumn{5}{c}{ Hasil Produksi Methanol (gram) } \\
\cline { 2 - 10 } & $\mathrm{Cu}$ & $\mathrm{Zn}$ & $\mathrm{Zr}$ & $220^{\circ} \mathrm{C}$ & $240^{\circ} \mathrm{C}$ & $250^{\circ} \mathrm{C}$ & $260^{\circ} \mathrm{C}$ & $280^{\circ} \mathrm{C}$ \\
\hline $\mathrm{CZZ}-1$ & 70 & 0 & 30 & 80 & 110 & 130 & 140 & 150 \\
\hline $\mathrm{CZZ}-2$ & 60 & 10 & 30 & 120 & 140 & 145 & 135 & 120 \\
\hline $\mathrm{CZZ}-3$ & 50 & 20 & 30 & 130 & 155 & 165 & 150 & 120 \\
\hline $\mathrm{CZZ}-4$ & 40 & 30 & 30 & 190 & 220 & 200 & 180 & 115 \\
\hline $\mathrm{CZZ}-5$ & 35 & 35 & 30 & 120 & 200 & 195 & 155 & 90 \\
\hline $\mathrm{CZZ}-6$ & 30 & 40 & 30 & 145 & 175 & 170 & 155 & 120 \\
\hline $\mathrm{CZZ-7}$ & 0 & 70 & 30 & 0 & 0 & 0 & 0 & 10 \\
\hline $\mathrm{CZZ-8}$ & 57.14 & 42.86 & 0 & 125 & 140 & 130 & 120 & 115 \\
\hline $\mathrm{CZZ}-9$ & 45.71 & 34.29 & 20 & 190 & 195 & 190 & 165 & 130 \\
\hline $\mathrm{CZZ}-10$ & 34.28 & 25.72 & 40 & 145 & 155 & 150 & 130 & 120 \\
\hline
\end{tabular}

\subsection{Fungsi Keanggotaan}

Fungsi keanggotaan adalah suatu fungsi dengan interval 0 sampai 1 yang merepresentasikan nilai input masing-masing variabel. Fungsi keanggotaan dibuat berdasarkan data pada Tabel 1. Seperti dalam Gambar 1, fungsi keanggotaan untuk komposisi $\mathrm{Cu}$ dan $\mathrm{Zn}$ adalah sedikit untuk komposisi dari $0 \%$ hingga $35 \%$, sedang untuk komposisi dari $11.6 \%$ hingga $58.3 \%$, dan banyak untuk komposisi dari $35 \%$ hingga $70 \%$. Kemudian untuk komposisi ZR

KINETIK Vol. 2, No. 1, Februari 2017: 1-8 
dijelaskan oleh Gambar 2, yaitu sedikit untuk komposisi dari $0 \%$ hingga $20 \%$, sedang untuk komposisi dari $6.6 \%$ hingga $33.3 \%$, dan banyak untuk komposisi dari $20 \%$ hingga $40 \%$. Lalu sesuai dengan Gambar 3 fungsi keanggotaan untuk suhu adalah dingin untuk suhu antara $220^{\circ} \mathrm{C}$ hingga $250^{\circ} \mathrm{C}$, sedang untuk suhu antara $230^{\circ} \mathrm{C}$ hingga $270^{\circ} \mathrm{C}$ dan panas untuk suhu antara $250^{\circ} \mathrm{C}$ hingga $280^{\circ} \mathrm{C}$. Hasil produksi methanol sesuai dengan Gambar 4 adalah sangat sedikit untuk hasil antara 0 gram hingga 100 gram, sedikit untuk hasil antara 80 gram hingga 150 gram, sedang untuk hasil antara 100 gram hingga 220 gram, banyak untuk hasil antara 160 gram hingga 220 gram.

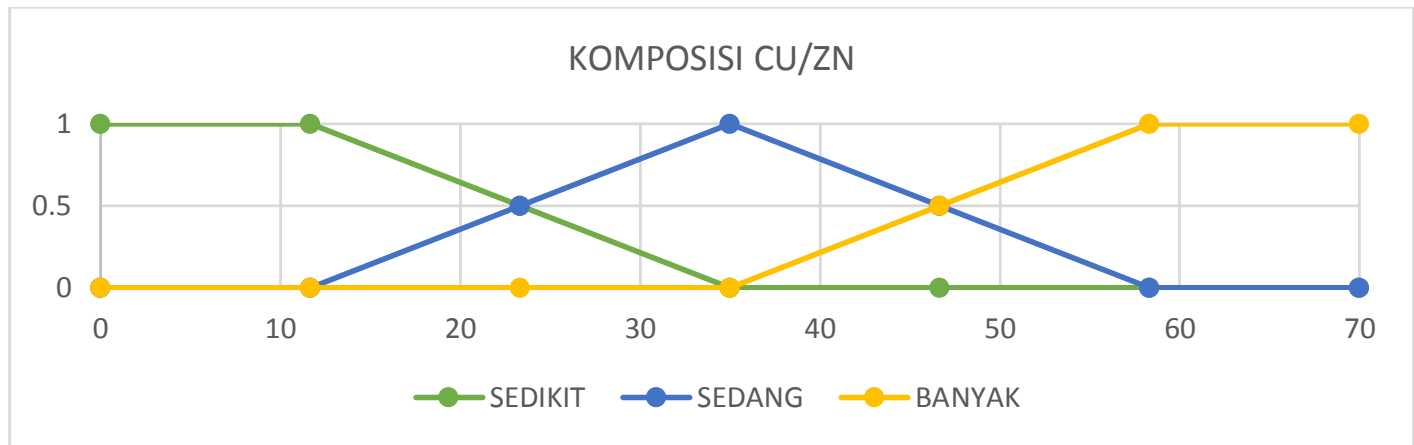

Gambar 1. Grafik Fungsi Keanggotaan untuk Komposisi Cu dan Zn

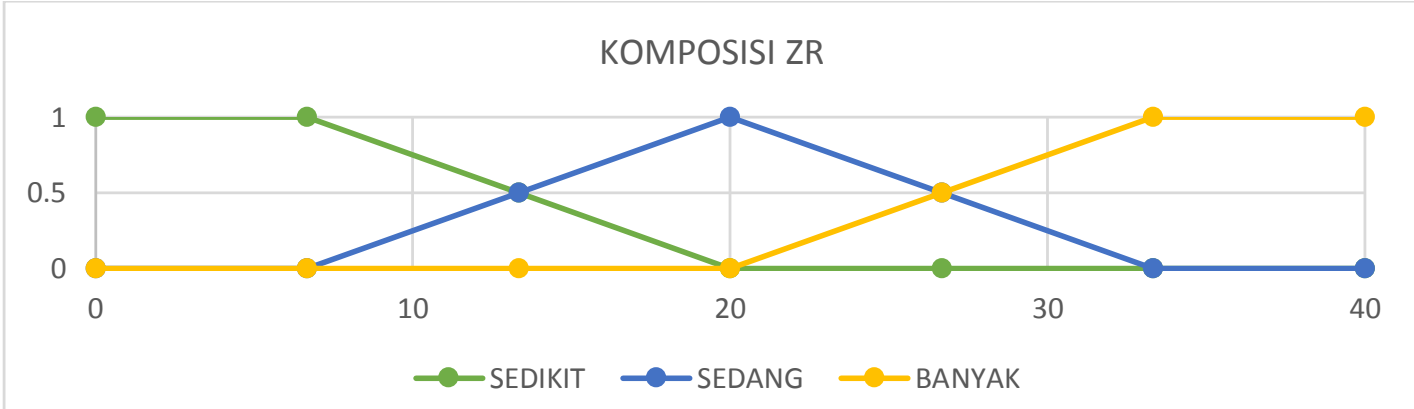

Gambar 2. Grafik Fungsi Keanggotaan untuk Komposisi Zr

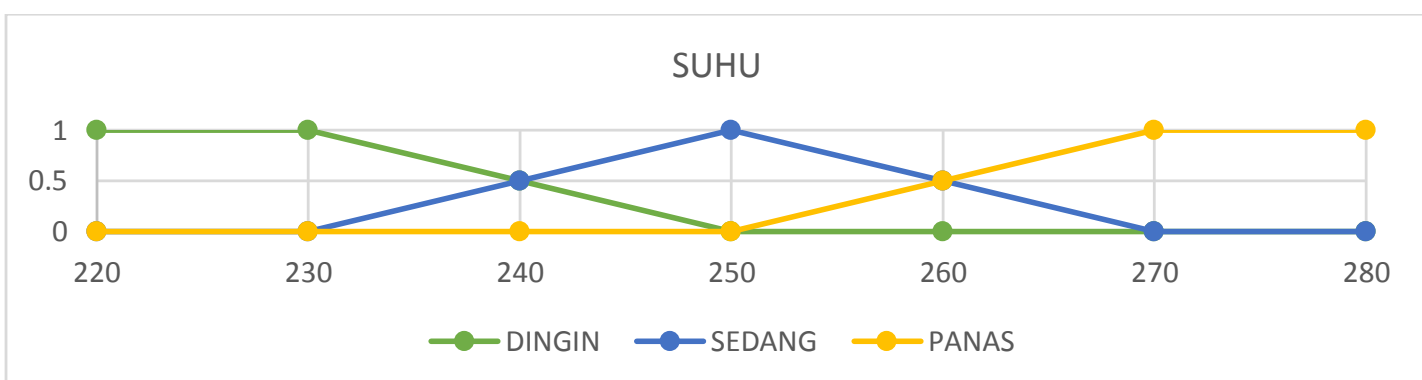

Gambar 3. Grafik Fungsi Keanggotaan untuk Suhu

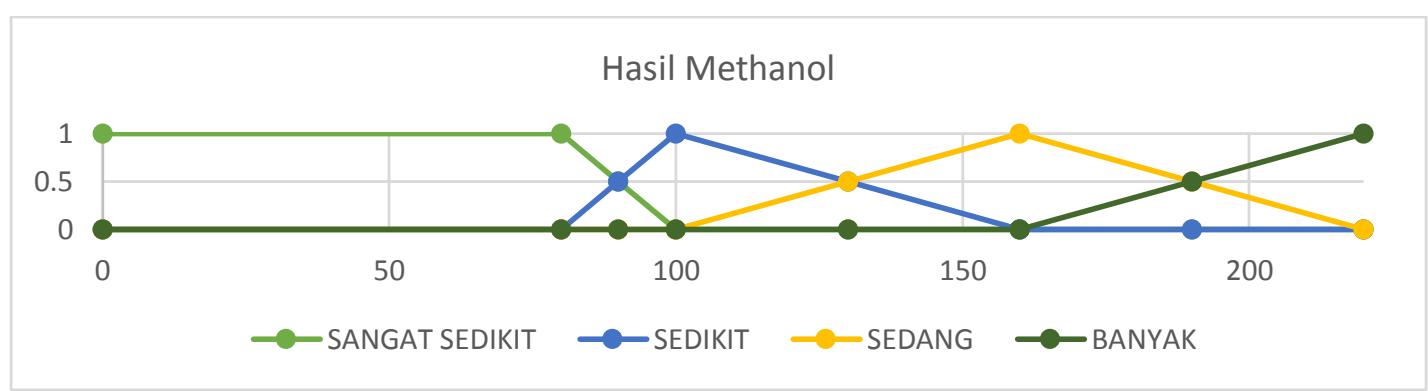

Gambar 4. Grafik Fungsi Keanggotaan untuk Hasil Produksi Methanol 


\subsection{Evolution Strategies}

Mengadaptasi proses evolusi yang terjadi pada makhluk hidup, algoritma evolution strategies memiliki beberapa tahapan meniru proses evolusi pada makhluk hidup. Awalnya algoritma evolution strategies memiliki sekumpulan individu dalam bentuk kromosom, membentuk sebuah populasi awal. Dari individu-individu ini akan terjadi proses reproduksi yang menghasilkan keturunan dengan mewarisi kromosom induknya. Induk yang baik akan berpeluang besar menghasilkan keturunan sifat baiknya pula. Selanjutnya dari bertambahnya jumlah populasi, dilakukan proses pemilihan individu menjadi penerus bagi generasi berikutnya. Hal ini dilakukan terus-menerus hingga keadaan berhenti telah tercapai.

\subsection{Representasi Kromosom}

Faktor penting menentukan keberhasilan algoritma evolusi dalam menemukan solusi dari pencarian masalah adalah seberapa baik representasi kromosom dibuat. Mencapai solusi optimal dalam mencari nilai komposisi dan suhu yang paling tepat, kromosom terdiri dari 4 segmen yang merupakan komposisi dari masing-masing katalis dan suhu yang dibutuhkan. Pada Tabel 2, kromosom pada segmen 1 berisi nilai $x$, yaitu variabel yang berubah naik atau turun untuk masing-masing katalis yang merepresentasikan seberapa besar nilai komposisi suatu katalis terhadap katalis lainnya. Pada Tabel 3, kromosom pada segmen 2 berisi nilai $\sigma$, karena nilai yang menentukan seberapa besar kenaikan atau penurunan pada variabel di segmen 1 dalam komposisi katalis dan kolom ke 4 di segmen 3 untuk suhu. Pada Tabel 4 , kromosom pada segmen 3 berisi nilai yang digunakan sebagai input untuk menghitung nilai fitness pada segmen 4 . Nilai pada kolom 1 sampai 3 pada segmen 3 selalu berjumlah $100 \%$ sehingga untuk menghitung nilai tersebut digunakan persamaan 1,2, dan 3 . Tabel 5 berisi nilai fitness dari metode Fuzzy dengan input kromosom pada segmen 3.

$$
\begin{aligned}
& \% C u=\frac{x C u}{(x C u+x Z n+x Z r)} \times 100 \% \\
& \% Z n=\frac{x Z n}{(x C u+x Z n+x Z r)} \times 100 \% \\
& \% Z r=\frac{x Z r}{(x C u+x Z n+x Z r)} \times 100 \%
\end{aligned}
$$

Tabel 2. Representasi Kromosom Segmen 1

$\mathrm{x} \mathrm{Cu} \times \mathrm{Zn} \quad \mathrm{Xr}$

Tabel 3. Representasi Kromosom Segmen 2

\begin{tabular}{cccc}
\hline$\sigma \mathrm{Cu}$ & $\sigma \mathrm{Zn}$ & $\sigma \mathrm{Zr}$ & $\sigma$ Suhu \\
\hline & Tabel 4. Representasi Kromosom Segmen 3 & \\
\hline$\% \mathrm{Cu}$ & $\% \mathrm{Zn}$ & $\% \mathrm{Zr}$ & ${ }^{\circ} \mathrm{C}$ Suhu \\
\hline
\end{tabular}

Tabel 5. Representasi Kromosom Segmen 4 fitness

\subsection{Inisialisasi Kromosom}

Pada tahap inisialisasi kromosom, dibangkitkan nilai secara acak untuk segmen 1, 2, dan kolom ke 4 pada segmen 3. Selanjutnya menghitung nilai untuk kolom 1-3 pada segmen 3 dengan persamaan 1,2, dan 3. Segmen 1 dan 2 berisi bilangan acak antara 0 sampai 1 , sedangkan kolom ke 4 pada segmen 3 berisi bilangan acak dengan rentang 220 sampai 280 . Kromosom yang dibangkitkan dibuat sebanyak jumlah populasi.

\subsection{Reproduksi}

Setiap individu yang terdapat dalam populasi, dilakukan proses reproduksi. Reproduksi adalah sebuah proses pembentukan individu baru dengan kromosom yang menyerupai induknya. Tujuannya adalah mencari individu-individu baru yang memiliki nilai fitness lebih baik. Dalam proses reproduksi, kromosom anak pada segmen 1 dan kolom 4 segmen 3 diisi dengan melakukan proses mutasi dengan cara menambahkan atau mengurangi segmen 1 dan kolom 4 
segmen 3 dalam induk, dengan segmen 2 pada induk yang dikalikan nilai acak $\mathrm{N}$ secara berurutan. Menurut penelitian [9], nilai $\mathrm{N}$ yang baik adalah suatu bilangan yang diperoleh menggunakan persamaan 5 . Selanjutnya nilai segmen 2 pada anak diisi dengan nilai segmen 2 pada parent dengan ketentuan dinaikkan 10\%, jika $20 \%$ dari anak memiliki nilai fitness lebih baik dan diturunkan $10 \%$ jika sebaliknya. Nilai segmen 4 pada anak diisi menggunakan metode Fuzzy dengan nilai segmen 3 pada anak sebagai input.

$$
N(0,1)=\sqrt{-2 \sin r 1} \sin 2 \pi r 2
$$

\subsection{Evaluasi Fungsi Fitness}

Fungsi fitness yang digunakan ditunjukkan pada Persamaan 6, dimana nilai fitness didapatkan menggunakan metode Fuzzy kemudian dikurangi nilai penalty, jika melanggar ketentuan sebagai berikut:

1. Nilai pada kolom 1 dan 2 segmen 3 tidak boleh lebih kecil dari 0 dan lebih besar dari 70 .

2. Nilai pada kolom 3 segmen 3 tidak boleh lebih kecil dari 0 dan lebih besar dari 40 .

3. Nilai pada kolom 4 segmen 3 tidak boleh lebih kecil dari 220 dan lebih besar dari 280 .

Untuk setiap ketentuan yang dilanggar, besar pelanggaran terhadap batas yang ditentukan dikalikan 1000 dan diakumulasikan sebagai nilai total penalty.

$$
\text { fitness }=\text { produksi dari fuzzy }- \text { penalty }
$$

\subsection{Seleksi}

Seleksi merupakan proses untuk menentukan individu mana yang akan menjadi penerus bagi generasi berikutnya. Seleksi menggunakan teknik elitism selection, yaitu memilih berdasarkan nilai fitness paling tinggi. Banyaknya individu yang lolos adalah sejumlah ukuran populasi dan yang berhak mengikuti seleksi adalah gabungan dari induk dan anak. Individu yang lolos seleksi akan masuk ke generasi berikutnya untuk menjadi induk dalam proses reproduksi selanjutnya.

\section{Hasil Penelitian dan Pembahasan}

Untuk mengetahui tingkat kesuksesan metode Fuzzy dan algoritma evolution strategies dalam mencari solusi yang terbaik dalam menentukan komposisi dan suhu yang tepat untuk katalis $\mathrm{CuO}-\mathrm{ZnO}-\mathrm{ZrO}_{2}$, maka perlu dilakukan beberapa pengujian. Pengujian yang dilakukan untuk metode Fuzzy adalah menguji tingkat akurasi, sedangkan algoritma evolution strategies dilakukan pengujian ukuran populasi, pengujian offspring, dan pengujian jumlah generasi. Setiap ukuran populasi, pengujian offspring, dan pengujian jumlah generasi dilakukan 10 kali pengujian, kemudian diambil nilai rata-rata nilai fitness yang didapatkan.

\subsection{Pengujian Akurasi Metode Fuzzy}

Saat menguji tingkat akurasi dari metode Fuzzy yang dibuat, dilakukan perbandingan antara hasil uji coba dari laboratorium dengan hasil perhitungan menggunakan metode Fuzzy. Dari data pada Tabel 6 menunjukkan nilai akurasi yang diperoleh dari metode Fuzzy sebesar $80.7 \%$.

\subsection{Pengujian Populasi}

Jumlah populasi yang sesuai untuk setiap permasalahan berbeda-beda. Maka, dilakukan pengujian populasi untuk mengetahui jumlah populasi yang tepat, sehingga diperoleh hasil optimal. Pengujian dilakukan dengan mencoba ukuran populasi antara 5 sampai 50 dengan ukuran offspring adalah 5 dan dijalankan sepanjang 50 generasi. Dari grafik pada Gambar 5 dapat disimpulkan, jika populasi kurang dari 10, maka hasil yang didapatkan tidak maksimal karena nilai fitness masih minimal dan sangat tidak stabil. Nilai fitness berada pada posisi stabil dengan nilai yang maksimal setelah populasi berjumlah diatas 30 . Pada jumlah populasi lebih dari 50 tidak terdapat perubahan signifikan, sehingga menambah ukuran populasi hanya akan membuang-buang waktu komputasi yang dibutuhkan. Meningkatkan ukuran populasi berpeluang meningkatkan hasil karena menambah daerah eksplorasi, namun ukuran populasi yang terlalu tinggi akan menambah waktu komputasi, sedangkan ukuran populasi yang terlalu sedikit akan mengurangi tingkat keberhasilan [10]. Oleh karena itu, diperlukan ukuran 
populasi yang tepat, agar mendapatkan hasil paling optimal dengan waktu komputasi yang sesuai.

Tabel 6. Perbandingan Hasil Laboratorium dengan Hasil Fuzzy

\begin{tabular}{|c|c|c|c|c|c|c|}
\hline $\mathrm{Cu}$ & $\mathrm{Zn}$ & $\mathrm{Zr}$ & Suhu & Lab & Fuzzy & Selisih \\
\hline 70 & 0 & 30 & 220 & 80 & 116.6667 & 36.66667 \\
\hline 70 & 0 & 30 & 240 & 110 & 126 & 16 \\
\hline 70 & 0 & 30 & 250 & 130 & 132.5 & 2.5 \\
\hline 70 & 0 & 30 & 260 & 140 & 135 & 5 \\
\hline 70 & 0 & 30 & 280 & 150 & 132.5 & 17.5 \\
\hline 60 & 10 & 30 & 220 & 120 & 116.6667 & 3.333333 \\
\hline 60 & 10 & 30 & 240 & 140 & 126 & 14 \\
\hline 60 & 10 & 30 & 250 & 145 & 132.5 & 12.5 \\
\hline 60 & 10 & 30 & 260 & 135 & 135 & 0 \\
\hline 60 & 10 & 30 & 280 & 120 & 132.5 & 12.5 \\
\hline 50 & 20 & 30 & 220 & 130 & 133.4615 & 3.461538 \\
\hline 50 & 20 & 30 & 240 & 155 & 143.4861 & 11.51386 \\
\hline 50 & 20 & 30 & 250 & 165 & 149.966 & 15.03401 \\
\hline 50 & 20 & 30 & 260 & 150 & 145.8896 & 4.11039 \\
\hline 50 & 20 & 30 & 280 & 120 & 137.415 & 17.41497 \\
\hline 40 & 30 & 30 & 220 & 190 & 151.4042 & 38.59578 \\
\hline 40 & 30 & 30 & 240 & 220 & 155.0251 & 64.97494 \\
\hline 40 & 30 & 30 & 250 & 200 & 172.8571 & 27.14286 \\
\hline 40 & 30 & 30 & 260 & 180 & 152.4848 & 27.5152 \\
\hline 40 & 30 & 30 & 280 & 115 & 136.7096 & 21.7096 \\
\hline 35 & 35 & 30 & 220 & 120 & 158.5 & 38.5 \\
\hline 35 & 35 & 30 & 240 & 200 & 164.1667 & 35.83333 \\
\hline 35 & 35 & 30 & 250 & 195 & 181.4286 & 13.57143 \\
\hline 35 & 35 & 30 & 260 & 155 & 157.5 & 2.5 \\
\hline 35 & 35 & 30 & 280 & 90 & 136.4286 & 46.42857 \\
\hline 30 & 40 & 30 & 220 & 145 & 153.5432 & 8.543233 \\
\hline 30 & 40 & 30 & 240 & 175 & 155.6101 & 19.38988 \\
\hline 30 & 40 & 30 & 250 & 170 & 172.0779 & 2.077922 \\
\hline 30 & 40 & 30 & 260 & 155 & 148.4582 & 6.541812 \\
\hline 30 & 40 & 30 & 280 & 120 & 131.987 & 11.98701 \\
\hline 0 & 70 & 30 & 220 & 0 & 85 & 85 \\
\hline 0 & 70 & 30 & 240 & 0 & 90 & 90 \\
\hline 0 & 70 & 30 & 250 & 0 & 85 & 85 \\
\hline 0 & 70 & 30 & 260 & 0 & 90 & 90 \\
\hline 0 & 70 & 30 & 280 & 10 & 85 & 75 \\
\hline 57.14 & 42.86 & 0 & 220 & 125 & 106.7371 & 18.26286 \\
\hline 57.14 & 42.86 & 0 & 240 & 140 & 135 & 5 \\
\hline 57.14 & 42.86 & 0 & 250 & 130 & 160 & 30 \\
\hline 57.14 & 42.86 & 0 & 260 & 120 & 135 & 15 \\
\hline 57.14 & 42.86 & 0 & 280 & 115 & 106.7371 & 8.262857 \\
\hline 45.71 & 34.29 & 20 & 220 & 190 & 192.46 & 2.46 \\
\hline 45.71 & 34.29 & 20 & 240 & 195 & 190 & 5 \\
\hline 45.71 & 34.29 & 20 & 250 & 190 & 192.46 & 2.46 \\
\hline 45.71 & 34.29 & 20 & 260 & 165 & 175 & 10 \\
\hline 45.71 & 34.29 & 20 & 280 & 130 & 160 & 30 \\
\hline 34.28 & 25.72 & 40 & 220 & 145 & 154.6971 & 9.697143 \\
\hline 34.28 & 25.72 & 40 & 240 & 155 & 162 & 7 \\
\hline 34.28 & 25.72 & 40 & 250 & 150 & 178.0686 & 28.06857 \\
\hline 34.28 & 25.72 & 40 & 260 & 130 & 155 & 25 \\
\hline 34.28 & 25.72 & 40 & 280 & 120 & 133.9771 & 13.97714 \\
\hline 34.28 & 25.72 & 40 & 280 & 120 & 133.9771 & 13.97714 \\
\hline
\end{tabular}




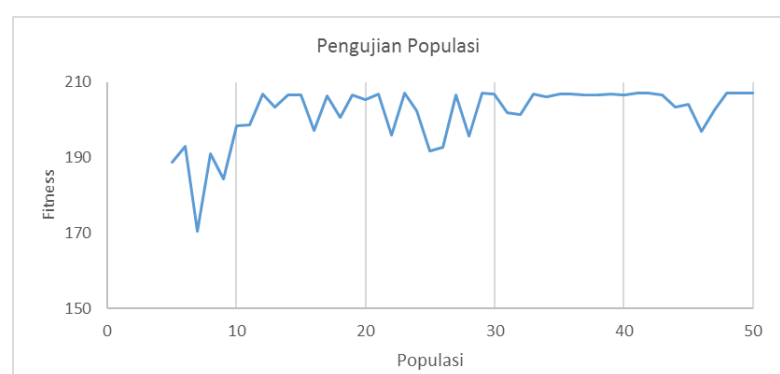

Gambar 5. Grafik Hasil Pengujian Ukuran Populasi

\subsection{Pengujian Offspring}

Pengujian offspring dilakukan untuk mendapatkan jumlah offspring yang sesuai dengan permasalahan yang dicari. Sama seperti ukuran populasi, nilai offspring yang tidak sesuai akan mengurangi tingkat keberhasilan dan menambah waktu komputasi. Maka ketepatan nilai offspring sama pentingnya seperti ukuran populasi yang tepat. Dalam pengujian ini, nilai offspring yang diuji coba berada pada besaran 1 sampai 30 offspring. Untuk populasi dan generasi masing-masing bernilai 10 dan 50. Dari grafik pada Gambar 6 terlihat ukuran offspring dengan nilai fitness paling tinggi dan stabil mulai terlihat pada besaran offspring diatas 20 . Sebelumnya, nilai fitness yang diperoleh belum maksimal dan masih berada dalam posisi labil.

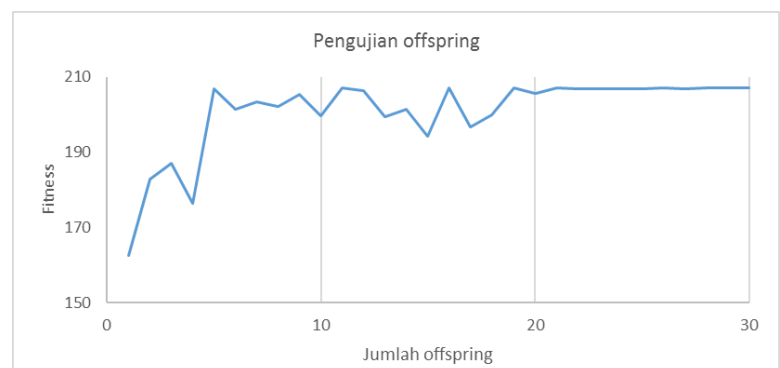

Gambar 6. Grafik Hasil Pengujian Jumlah Offspring

\subsection{Pengujian Generasi}

Generasi merupakan ukuran berapa kali reproduksi dan seleksi diulang. Semakin banyak ukuran generasi, maka dapat dipastikan perolehan hasil akan semakin baik. Namun ukuran generasi yang terlalu besar tidak akan memberi pengaruh signifikan ketika nilai fitness paling optimal telah dicapai dan hanya akan membuang-buang waktu komputasi. Oleh karena itu, ukuran generasi yang tepat akan menghemat waktu dengan perolehan hasil yang tetap optimal. Uji coba jumlah generasi berada pada rentang 10 sampai 100 dengan besaran populasi dan offspring adalah 10. Dari hasil grafik pada Gambar 7, terjadi kestabilan nilai fitness ketika generasi menyentuh angka 70 . Setelah itu terjadi beberapa penurunan nilai fitness dan hal tersebut dapat dipahami karena evolution strategies merupakan algoritma yang bersifat stochastic.

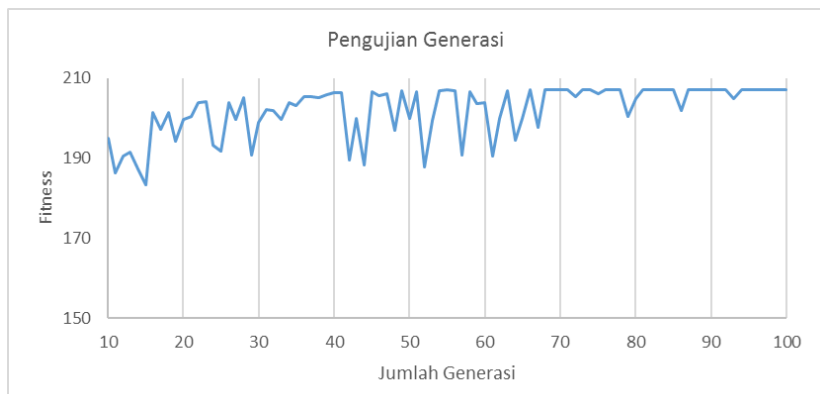

Gambar 7. Grafik Hasil Pengujian Generasi

\subsection{Pengujian Suhu dan Jumlah Komposisi Katalis CuO-ZnO-ZrO}

Dengan menggunakan nilai yang didapatkan pada pengujian sebelumnya, yaitu populasi sebesar 30 , offspring sebesar 10 , dan generasi sebanyak 100 . Didapatkan hasil 
komposisi dengan produksi methanol paling banyak sebesar 207 gram pada angka $39.9 \% \mathrm{Cu}$, $40 \% \mathrm{Zr}$, dan $19.9 \% \mathrm{Zn}$ dengan suhu $229.9^{\circ} \mathrm{C}$ dan $250^{\circ} \mathrm{C}$. Melihat kebutuhan energi untuk mencapai suhu $229.9^{\circ} \mathrm{C}$ lebih sedikit daripada kebutuhan energi untuk mencapai suhu $250^{\circ} \mathrm{C}$, maka dapat diputuskan bahwa komposisi dan suhu paling optimal ada di angka $39.9 \% \mathrm{Cu}, 40 \%$ $\mathrm{Zr}$, dan $19.9 \% \mathrm{Zn}$ dengan suhu $229.9^{\circ} \mathrm{C}$.

\section{Kesimpulan dan Saran \\ 4.1 Kesimpulan}

Berdasarkan hasil pada pengujian-pengujian yang telah dilakukan, dapat ditarik kesimpulan bahwa keberhasilan perolehan solusi sangat tergantung terhadap parameterparameter yang digunakan seperti ukuran populasi, ukuran offspring, dan banyaknya generasi. Selain itu, metode yang digunakan untuk menghitung nilai fitness memberikan peran yang sangat besar terhadap solusi yang dihasilkan. Gabungan antara algoritma evolution strategies dan metode Fuzzy Tsukamoto dalam menentukan jumlah komposisi dan suhu pada produksi methanol menghasilkan solusi $39.9 \% \mathrm{Cu}, 40 \% \mathrm{Zr}$, $19.9 \% \mathrm{Zn}$ dengan suhu $229.9^{\circ} \mathrm{C}$ dan menghasilkan produksi methanol sebanyak 207 gram. Kelebihan menggunakan gabungan algoritma ini adalah tidak perlu menguji semua kombinasi komposisi di laboratorium, hanya dengan melakukan beberapa percobaan dapat dicari kombinasi komposisi yang paling optimal. Namun kelemahannya adalah kombinasi yang dihasilkan sangat bergantung kepada banyaknya data hasil uji coba dari laboratorium, semakin banyak kombinasi pengujian, maka tingkat akurasi akan semakin meningkat. Selain itu, komposisi yang dihasilkan hanya berupa perkiraan, sehingga perlu dilakukan uji coba di laboratorium untuk membuktikan kebenaran hasil dari penelitian ini.

\subsection{Saran}

Untuk penelitian selanjutnya, dapat dilakukan dengan memperbaiki metode Fuzzy Tsukamoto yang digunakan sebagai pengujian nilai fitness. Metode Fuzzy Tsukamoto hanya memperoleh akurasi sebesar $80.7 \%$, angka ini dapat ditingkatkan dengan mengoptimasi fungsi keanggotaan dari masing-masing input menggunakan algoritma evolusi lain, seperti algoritma genetika. Selain itu dapat dilakukan pengujian fungsi nilai fitness dengan menggunakan metode Fuzzy lainnya, seperti Fuzzy Mamdani dan Fuzzy Sugeno, bahkan menggunakan metode Fuzzy yang lebih baik seperti Neuro Fuzzy.

\section{Referensi}

[1] G. Centi and S. Perathoner. "Opportunities and prospects in the chemical recycling of carbon dioxide to fuels." Catal. Today. Vol. 148. 3-4 (2009): 191-205.

[2] E. E. Ortelli, J. Wambach, and A. Wokaun. "Methanol synthesis reactions over a CuZr based catalyst investigated using periodic variations of reactant concentrations," Appl. Catal. A Gen. Vol 216. 1-2 (2001): 227-241.

[3] G. A. Olah, A. Goeppert, and G. K. S. Prakash. Beyond Oil and Gas: The Methanol Economy: Second Edition. Wiley-VCH Verlag GmbH \& Co. KGaA, 2009.

[4] D. R. Palo, R. A. Dagle, and J. D. Holladay. "Methanol steam reforming for hydrogen production." Chemical Reviews. Vol. 107. 10 (2007): 3992-4021.

[5] G. A. Olah, A. Goeppert, and G. K. S. Prakash. "Chemical recycling of carbon dioxide to methanol and dimethyl ether: From greenhouse gas to renewable, environmentally carbon neutral fuels and synthetic hydrocarbons." Journal of Organic Chemistry. Vol. 74.2 (2009): 487-498.

[6] X. Liu, G. Lu, Z. Yan, and J. Beltramini. "Recent advances in catalysts for methanol synthesis via hydrogenation of $\mathrm{CO}$ and $\mathrm{CO} 2, "$ Industrial \& Engineering Chemistry Research 42.25 (2003): 6518-6530.

[7] S. G. Jadhav, P. D. Vaidya, B. M. Bhanage, and J. B. Joshi. "Catalytic carbon dioxide hydrogenation to methanol: A review of recent studies," Chemical Engineering Research and Design. 92.11 (2014): 2557-2567.

[8] T. Witoon, N. Kachaban, W. Donphai, P. Kidkhunthod, K. Faungnawakij, M. Chareonpanich, and J. Limtrakul. "Tuning of catalytic $\mathrm{CO} 2$ hydrogenation by changing composition of $\mathrm{CuO}-$ ZnO-ZrO2 catalysts." Energy Conversion and Management 118 (2016): 21-31.

[9] H. P. Schwefel. "Evolution and Optimum Seeking." John Wiley \& Sons, Inc. 1995.

[10]W. F. Mahmudy, R. M. Marian, and L. H. S. Luong. "Real Coded Genetic Algorithms for Solving Flexible Job-Shop Scheduling Problem - Part I: Modelling." Adv. Mater. Res., Vol. 701 (2013): 359-363. 